ARTIGOS 



\section{A tributação sobre a escravidão e o comércio de escravos na província de Minas Gerais}

\section{Daniel do Val Cosentino*}

Resumo: O presente trabalho estuda a tributação sobre a escravidão na província de Minas Gerais. A partir deste estudo, acreditamos que seja possível traçar um perfil do sistema escravista e do comércio de escravos na província, principalmente no período de crise do sistema escravista no Brasil, a partir da segunda metade do século XIX.

Palavras-chave: escravidão; comércio de escravos; tributos.

Abstract: This paper analyzes the slavery taxes in the province of Minas Gerais. These taxes allow the knowledge of the slave system and the slave trade in the province during the crisis of slavery in Brazil in the second half of the nineteenth century.

Keywords: slavery; slave trade; taxes.

A tributação sobre a escravidão em Minas Gerais no século XIX não é assunto presente na historiografia econômica. No livro História financeira de Minas Gerais, Antonio Luiz de Bessa, ${ }^{1}$ não faz menção a tributos que incidiam sobre a escravidão nos tempos da província de Minas Gerais. Em Política econômica do governo provincial Mineiro, Francisco Iglésias2 também não aborda a questão na seção dedicada às finanças da província mineira.

Acreditamos que a análise da história da tributação sobre a escravidão no século XIX pode ser um importante instrumento para o estudo dessa instituição. No nosso período específico, segunda metade do século XIX, o assunto pode refletir questões tais como a crise e o processo de abolição da escravatura, bem como a transição para o trabalho livre.

Uma parte significativa das discussões parlamentares, encontradas nos Anais da Assembleia Legislativa Provincial, dava-se por ocasião da fixação do Orçamento Provincial. Tanto as discussões sobre a fixação das receitas e implementação de

* Professor da Universidade Federal de Ouro Preto e doutorando em História Econômica pela USP. E-mail: dcosentino@terra.com.br

1 BESSA, Antonio Luiz de. Historia financeira de Minas Gerais em 70 anos de Republica. Belo Horizonte: Imp. Oficial, 1981.

2 IGLESIAS, Francisco. Política econômica do governo provincial mineiro (1835-1889). Rio de Janeiro: Ministério da Educação e Cultura, Instituto Nacional do Livro, 1958. 
tributos, bem como o planejamento das despesas ocupavam um grande espaço na pauta das discussões das sessões parlamentares.

A pesquisa nos Anais da Assembleia Provincial aponta para o fato de que boa parte dos debates parlamentares sobre as questões relativas à escravidão na Província, durante a década de 1870 , dava-se em torno do Orçamento Provincial, discussões derivadas da cobrança de impostos sobre a escravidão. ${ }^{3}$

Um breve histórico dos impostos que incidiam sobre a escravidão na história provincial mineira pode ser encontrado nas leis mineiras, especificamente nas leis que fixavam o orçamento ano a ano.

Como aponta Francisco Iglésias, por muitos anos, desde o primeiro exercício financeiro - de $1^{\circ}$ de julho de 1835 a 30 de junho de 1836 -, o orçamento fixava apenas a despesa, sendo que, no referente à receita, estipulava os tributos, mas não o montante que se esperava arrecadar. Segundo Iglesias, "Com informações incompletas, ou mesmo falsas, desconhecendo aspectos do problema e com legislação imperfeita em matéria de fixação de competências, a tarefa orçamentária da Província não era fácil”. ${ }^{4}$ Somente em 1875, com a Lei $\mathrm{n}^{\circ} 2121$ de 8 de Janeiro, que fixou o orçamento para o ano financeiro de 1875-1876, é que a receita passa a ser calculada. ${ }^{5}$

Desde a primeira lei que fixou o orçamento provincial, o imposto sobre compra e venda de escravos aparece estipulado. Era o imposto da meia sisa, que aparecia como principal fonte de arrecadação e que incidia sobre a escravidão até a abolição em 1888.

Basicamente, são três as fontes de arrecadação que incidiam sobre a escravidão e que tiveram continuidade, desde o início de sua cobrança até a abolição. Além da meia sisa (compra e venda de escravos), com a Lei $n^{\circ} 1811$, de 10 de outubro de 1871, que fixava o orçamento para o ano financeiro de 1871-1872, estabeleceu-se um imposto que incidiria sobre escravos empregados na mineração de ouro. $O$ tributo seria cobrado sobre cada escravo que fosse empregado, direta ou indiretamente, no serviço de mineração de ouro de qualquer companhia ou mesmo particular, quando este estivesse empregando no serviço mais de cinco escravos. ${ }^{6}$

Outro imposto cobrado até o fim da escravidão foi o que incidia sobre o comércio de escravos. Estabelecido com a Lei Orçamentária $n^{\circ} 2024$, de $1^{\circ}$ de dezembro de 1873, que fixou receitas e despesas para o ano financeiro de 18741875 , o tributo procurava taxar os comerciantes de escravos. Ele seria cobrado, no valor de um conto de réis anuais, de cada pessoa que comercializasse escravos, comprando-os para revender.?

$\mathrm{Na}$ mesma lei, fixava-se outro imposto que procurava taxar a saída de escravos de Minas Gerais. Seriam cobrados 200 réis sobre cada escravo que fosse conduzido para fora da província. ${ }^{8}$ Tal imposto foi suprimido pela lei orçamentária do ano seguinte. 9

3 Advertimos o leitor que, ao transcrever e citar no corpo do texto os discursos parlamentares optamos por manter a grafia original das palavras, por entender que uma eventual atualização ortográfica e gramatical poderia incorrer no risco de modificar e comprometer o sentido histórico do texto e da própria fonte. Assim, em consonância às normas ABNT, adicionamos às citações de época o termo sic após as palavras com grafia e concordância antigas.

4 IGLESIAS, Francisco. op. cit., p. 175.

5 Arquivo Público Mineiro, Leis Mineiras de 1874, Lei n 2112 de 8 de janeiro de 1875.

6 Arquivo Público Mineiro, Leis Mineiras de 1871, Lei nº 1811 de 10 de outubro de 1871.

7 Arquivo Público Mineiro, Leis Mineiras de 1873, Lei $n^{\circ} 2024$ de $1^{\circ}$ de dezembro de 1873.

8 Idem.

9 Arquivo Público Mineiro, Leis Mineiras de 1875, Lei nº 2181 de 25 de novembro de 1875. 
Esse imposto sobre a saída de escravos da província já havia sido estabelecido uma vez na Lei orçamentária no 869 de 5 de julho de $1858 .^{10}$ Entretanto, nos anos seguintes, as leis orçamentárias não fizeram qualquer referência a tal tributo, nem mesmo para revogá-lo. O que parece interessante observar é que a tentativa de cobrar um imposto sobre a saída de escravos, em 1858, coincidia com um período no qual a província ainda devia sentir o impacto do fim do tráfico internacional de escravos, e com uma época em que o tráfico interprovincial ainda não estava plenamente organizado. ${ }^{11}$

Roberto Martins ${ }^{12}$ afirma que a província de Minas Gerais foi uma das maiores importadoras de escravos do Brasil até a década de 1870. Reafirmando a maioria das conclusões de seus trabalhos, ${ }^{13}$ o autor aponta para o fato de que mesmo depois de 1850 , com o fim do tráfico internacional de escravos, a província mineira importava escravos em grande quantidade, e que esses cativos não estariam ligados, necessariamente, à região cafeeira da zona da mata mineira.

A tentativa de se estabelecer um imposto sobre a saída de escravos, em 1873, também é uma questão instigante. A interpretação de tal tributo apresenta diversas possibilidades. Por um lado, podemos imaginar que até o início da década de 1870 a província não sofria com a transferência de escravos para as regiões cafeeiras de São Paulo e Rio de Janeiro (o que confirmaria algumas das hipóteses levantadas por Martins), sendo que, a partir daí, a transferência de escravos obrigou as autoridades a tentarem proteger Minas Gerais da carestia do braço cativo.

Contudo, a revogação do tributo, um ano depois, sugere, primeiro, que sua cobrança não deveria ser uma unanimidade no Parlamento e, segundo, que ela não deveria causar tantos impactos. O que sugere que a província poderia não estar perdendo escravos para outras regiões. Isso porque reconhecendo a grande diversidade regional da província, a realidade econômica de cada região ${ }^{14}$ teria impactos diferenciados no referente à necessidade da venda de escravos, etc. Dessa forma, existiam regiões que estavam perdendo escravos ao mesmo tempo em que outras ainda compravam escravos.

Nas discussões do projeto de lei que fixou o orçamento para o ano fiscal de 1874-1875, encontramos debates a respeito dos impostos sobre a escravidão. $O$ primeiro a levantar a questão foi o deputado pelo $2^{\circ}$ distrito, o dr. Gustavo Xavier da Silva Capanema, ${ }^{15}$ durante a $38^{\circ}$ Sessão Ordinária de 6 de novembro de 1873 , na qual se discutia o projeto $\mathrm{n}^{\circ} 26$, que fixava o orçamento.

\section{O deputado questionava a proposta de tributar a saída de escravos da província}

10 Arquivo Público Mineiro, Leis Mineiras de 1858, Lei nº 869 de 5 de julho de 1858.

11 São vários os depoimentos de autoridades dos mais diversos municípios mineiros reclamando da falta de braços no período. Ver COSENTINO, Daniel. Um múltiplo de transições: a transição do trabalho escravo para o trabalho livre em Minas Gerais. Dissertação (Mestrado), UNICAMP, 2006.

12 MARTINS, Roberto Borges. "Minas e o tráfico de escravos no século XIX, outra vez". In: SZMRECSÁNYI, Tamás \& LAPA, José Roberto do Amaral (orgs.). História Econômica da Independência e do Império. São Paulo: Hucitec/ABPHE/Edusp/Imprensa Oficial, 2002.

13 MARTINS, Roberto B. A economia escravista de Minas Gerais no século XIX. Belo Horizonte: Cedeplar/UFMG, 1980a; MARTINS, Roberto B. Growing in Silence: The Slave Economy of Nineteenth-Century Minas Gerais, Brazil. Tese (Doutorado), Varderbilt University, 1980b.

14 PAIVA, Clotilde Andrade. População e Economia nas Minas Gerais do século XIX. Tese (doutorado) USP/ Faculdade de Filosofia, Letras e Ciências Humanas, 1996; PAIVA, Clotilde Andrade \& GODOY, Marcelo Magalhães. "Território de contrastes: economia e sociedade das Minas Gerais do século XIX”. In: SILVA, Francisco Carlos Teixeira da; MATTOS, Hebe Maria; FRAGOSO, João (orgs.). Escritos sobre História e educação: homenagem a Maria Yedda Leite Linhares, Rio de Janeiro: Mauad e Faperj, 2001.

15 O deputado Gustavo Capanema era chefe político da cidade de Muriaé, seu filho Gustavo Capanema Filho foi um político de destaque na República, tendo sido governador de Minas Gerais. 
por acreditar que tal imposto iria aumentar o preço dos mesmos, dificultando, além dessa saída, a extinção da escravidão em Minas Gerais. Segundo ele,

subindo o imposto a $200 \$ 000 \mathrm{rs}$. [sic] sobre cada escravo, é óbvio que os escravos deixarão de ser conduzidos para fora da província, afim de serem vendidos, e os compradores, que queirão [sic] aventurar a compra, terão de elevar muito o preço da venda, e em taes [sic] condições não acharão mais quem queira comprar escravos para fora da província, e assim se difficultará [sic] cada vez mais a extinção da escravidão na província de Minas, facto [sic] aliás que todos nós desejamos ver o quanto antes. ${ }^{16}$

Além de questionar a adoção do imposto, o deputado foi além e propôs uma emenda que alterasse o texto do projeto de forma que se passasse a taxar a entrada de escravos na província, e não a saída.

\begin{abstract}
parecendo-me, como disse, que a emenda vae [sic] por óbices a fácil exportação de escravos da província, e reconhecendo por isso que vae ella abstar [sic] a abolição da escravatura em menos tempo, entendo que ella [sic] não deve ser aceita pela Casa tal como se acha redigida: e reconhecendo vice-versa que uma medida em sentido contrario opporia [sic] barreira á entrada de escravos para a nossa província, não avultando portanto o numero dos nossos, que a pouco e pouco irão se reduzindo, penso que a redação ficaria melhor si, em vez da palavra para fora, - se dissesse - para dentro. ${ }^{17}$
\end{abstract}

A proposta do deputado foi questionada por alguns apartes que reclamavam ser esta prejudicial à lavoura. Para o deputado Gustavo Capanema, a lavoura não seria prejudicada "porque só venderão escravos aquelles [sic] que os tiverem em excesso, ou que já não podem trabalhar". ${ }^{18} \mathrm{O}$ deputado justificava sua proposta como uma "ideia do futuro", apontado que Minas seria a primeira província brasileira a realizar a emancipação.

Um questionamento interessante à emenda foi feito pelo deputado do $4^{\circ}$ distrito, dr. Salathiel de Andrade Braga, que afirmava que "Tirar o escravo da província de Minas para leval-o [sic] para o Rio de Janeiro, não é mais do que deslocar a escravidão."19

É difícil imaginar tamanho sentimento abolicionista em uma província tão marcada pelo apego à escravidão. Ao questionar a emenda do deputado Capanema, o deputado Salathiel dizia que defendia a manutenção do status quo e que não se devia criar qualquer imposto que incidisse sobre a entrada ou saída de escravos na província.

Si na província de Minas há tanto enthusiasmo [sic] por essa idea [sic] de liberdade, quem impede os senhores de passar carta a seus escravos? Assim, não ficarião [sic] todos elles [sic] livres? Porque não

\footnotetext{
16 Arquivo Público Mineiro - Anais da Assembleia Legislativa Provincial de Minas Gerais de $1873,38^{\circ}$ Sessão Ordinária de 6 de novembro de 1873.

17 Idem.

18 Idem.

19 Idem.
} 
acontece isto? Porque há necessidade de braços para a lavoura. Foi por isto, Sr. Presidente, que eu disse, em aparte ao nobre deputado pelo $2^{\circ}$ distrito: supprimão [sic] a lavoura. Com effeito [sic], onde estão os braços para substituírem os que faltariam á lavoura? Nós vemos hoje a carestia dos gêneros n'esta cidade, que é, entretanto, a capital da província; a que é devido isto? Porque se da esse facto [sic]? Porque todos os annos [sic] vão faltando braços para a lavoura. Os fazendeiros, que plantavão [sic] grande porção de feijão, milho e outros cereaes [sic], tem visto diminuir essas plantações, porque os braços faltão-lhes [sic]. Si elles [sic] podem vender seus escravos para fora da província, porque obtinhão [sic] maio preço, como se ha-de oppor [sic] um obstáculo a esse meio de augmentar [sic] sua prosperidade? Não vejo necessidade disto; ao contrario, me parece que devemos manter o status quo.20

O deputado Gustavo Capanema procurou justificar-se, afirmando que não era um apologista do comércio de escravos, mas que acreditava que, sendo o escravo uma propriedade garantida pela lei, poderia ser comercializado.

(...) comquanto [sic] eu e quasi [sic] todos sejamos inimigos desse commercio [sic], não podemos deixar de toleral-o [sic], porque o escravo é uma propriedade, e toda propriedade pode ser transferida, porque as leis do Estado o permittem [sic]; e desde que as leis do Estado o permittem [sic], não posso ser censurado de tolerar o commercio [sic] de escravos, não podendo de maneira alguma por isso ser considerado apologista d'elle [sic].

E terminou justificando novamente sua posição de querer ver, o quanto antes, a escravidão extinta na província, além de argumentar que a lavoura não seria prejudicada, uma vez que a substituição do trabalho escravo pelo trabalho livre seria feita proporcionalmente à diminuição da escravidão.

Srs., convirjamos todas as nossas attenções [sic] para a abolição do elemento servil no império brasileiro, mas cuide cada província em reduzir de um modo rápido, comtanto [sic] que seja legal, o numero de seus escravos. É este o meu modo de pensar. Eu desejo que o Brazil [sic] inteiro não conte escravos em seu seio, mas maior desejo é que a província de Minas seja a primeira que se veja completamente livre da escravidão.

[...] Si a lavoura soffre actualmente [sic], si bem que pouco, porque a substituição do braço escravo pelo braço livre irá sendo proporcionalmente feita, fica-nos entretanto a consolação de que não sofrerá a geração futura, uma vez que fique esturpado [sic] esse cancro, que lhe poderá ser funesto. Eu, portanto, com vistas no futuro, entendo que a emenda do nobre deputado, pondo óbices á sahida [sic] dos escravos para fora da província, não é conveniente; a conveniência, que V. Exc. [sic] disse d'ahi [sic] resultava, é muito inferior ao inconveniente que apontei.

A emenda do deputado Gustavo Capanema foi rejeitada. Contudo, seu depoimento reforça a tese de que o tráfico de escravos não tinha necessariamente o mesmo impacto em todas as regiões da província.

20 Idem. 
Na mesma sessão uma nova emenda foi proposta, e dizia respeito, justamente, à taxação do comércio de escravos. A emenda que deu origem ao imposto sobre o comércio de escravos foi aprovada e deu origem a um debate bastante interessante.

O debate sobre a adoção do imposto sobre o comércio de escravos refletia opções ideológicas dos deputados. Os que eram a favor do tributo acreditavam que se deveria impedir o tráfico de carne humana, enquanto os que eram contra acreditavam que tal imposto era um obstáculo à liberdade de comércio, além de prejudicial à lavoura por causar aumento indireto dos preços dos escravos.

O discurso do deputado dr. Caetano Augusto da Gama Cerqueira ${ }^{21}$ refletiu bem não só o porquê de sua discordância quanto à adoção do tributo sobre comércio de escravos, mas também sua posição política e pessoal sobre o significado da escravidão. O deputado argumentou que o escravo era, reconhecidamente por lei, uma propriedade, e por isso deveria ser respeitado como tal.

Si é contra a moral, si é contra os preceitos do Evangelho, si é uma traficância, essa traficância só poderia deixar de existir, si se tivesse de um golpe acabado com a escravidão; mas, desde que os poderes geraes [sic] reconhecerão essa propriedade, garantida como qualquer outra, e apenas a limitou, nós devemos respeital-a [sic], não podemos lançar sobre ella [sic] um imposto como aquele que se pretende lançar, e que não vamos estender á transmissão de outras propriedades.

Nós não podemos deixar de reconhecer que, segundo as leis, o escravo é constituído na posição de cousa $[$ sic $][\ldots . . .]^{22}$

O deputado procurou justificar a sua posição e a afirmação de considerar o escravo como "coisa", dizendo que somente "coisas" poderiam ser consideradas propriedade.

[...] Desde que o escravo é propriedade, está em regra nivelado com as cousas, porque só cousas podem ser objecto [sic] de propriedade (isto é o que é o principio de direito); mas, como não era possível, philosoficamente fallando [sic], que um homem se constituísse em todos os sentidos na posição de cousa, concederão-se [sic] aos escravos certos direitos, que não são compatíveis propriamente com as cousas, porque não se podia adulterar a sua natureza, a sua alma dotada das mesmas faculdades. Por essa razão já mesmo o direito romano moderno concedeo [sic] aos escravos certos direitos, que não são compatíveis com a expressão cousa no seu sentido restricto [sic]. [...] Eu digo, em these [sic], que desde que o escravo é propriedade, está na posição de cousa; do contrário era impossível, segundo os princípios mais comesinhos de direito, que elle [sic] constituísse objeto de propriedade, reconhecida, mas limitada, por nossas leis; porque sendo uma propriedade que eu denominarei sui generis [sic], não era possível

21 O deputado Gama Cerqueira foi político, magistrado e procurador. Nasceu em São João Del Rey em 1839, iniciou sua carreira jurídica como promotor público em Campanha. Ingressou na magistratura, na qual exerceu o cargo de juiz municipal nas comarcas de Pomba e Ponte Nova e o Juizado de Direito em Campanha, Oliveira e Conceição do Serro. Depois de cumprir o mandato de deputado provincial nos anos de 1872-1873, foi secretario geral da Polícia. Já sob o regime republicano, foi nomeado desembargador do Tribunal da Relação e, em seguida, procurador geral do Estado. GÓES, Norma de (org.). Dicionário Biográfico de Minas Gerais - Período Republicano 1889/1991. Belo Horizonte: UFMG/Assembleia Legislativa do Estado de Minas Gerais, 1994, p. 172.

22 Arquivo Público Mineiro - Anais da Assembleia Legislativa Provincial de Minas Gerais de $1873,38^{\circ}$ Sessão Ordinária de 6 de novembro de 1873. 
que fosse em tudo completamente equiparada a propriedade sobre os objetos, que são cousas, no sentido jurídico e philosofico [sic]. Por esta razão, em bem da humanidade, e segundo os princípios philosoficos [sic], a nossa legislação concedeo [sic] aos escravos certos direitos, que já lhes eram concedidos pelo direito romano, e até os ampliou. ${ }^{23}$

Ele terminou afirmando a dupla condição do escravo, como pessoa e como “coisa”, propriedade garantida pelas leis do Império e, por isso, transmissível como qualquer outra propriedade. Por isso, colocava-se contrário à adoção do tributo.

Ninguém poderá contestar que, segundo, as nossas leis, o escravo é propriedade e portanto transmissível, como qualquer outra. O poder do senhor sobre o escravo, o dominica potestas [sic] dos Romanos, composta do dominium [sic] e do potestas [sic], impõe ao escravo dupla subjetividade ao senhor, e o constitue [sic] ao mesmo tempo na posição de cousa e de pessoa: em relação ao domínio elle [sic] é cousa, ele relação ao poder é pessoa.

Como cousa é objeto de propriedade, reconhecida por nossas leis e pela própria lei de 28 de setembro, com razão denominada a lei áurea, portanto garantida pela Constituição do Império.

[...] Como havemos de impedir que haja commercio [sic], quando as leis reconhecem a existência desta propriedade, e a assembléa [sic] provincial é incompetente para negar ou cercear esse direito?

[...] não sendo um comercio ilícito, não pode merecer censura. Si assim mesmo não fosse, o poder competente, que tem empregado todos os meios para acabar com a escravidão, devia ter acabado também como o commercio [sic] de escravos. Entretanto, este poder reconheceu o direito de propriedade, e limitou-o quanto era possível, para que desaparecesse essa propriedade no Brazil [sic], mas respeitou as conseqüências, que decorrem desse direito. Portanto Sr. Presidente, acho que é este um imposto injustificável e vexatório. ${ }^{24}$

A emenda que propunha o imposto sobre o comércio de escravos foi aprovada e o imposto, como afirmamos anteriormente, esteve presente até a abolição da escravidão, em 1888.

No ano de 1875 , com a Lei Orçamentária $n^{\circ} 2181^{25}$ de 25 de novembro, foi estabelecida uma taxa sobre o registro de escravos. Tal taxa passou a aparecer estimada a cada ano no orçamento, juntamente com a rubrica do imposto da meia sisa sobre compra e venda de escravos.

Durante os últimos anos da década de 1870, sempre que foram discutidos os projetos orçamentários na Assembleia Legislativa Provincial, houve debates e questionamentos em torno das estimativas que eram feitas a respeito da arrecadação dos impostos que incidiam sobre a escravidão.

$\mathrm{Na}$ sessão de 28 de outubro de 1877, durante o debate em torno do orçamento, o deputado Candido Luiz Maria de Oliveira ${ }^{26}$ questionou as estimativas

23 Idem.

24 Idem.

25 Arquivo Público Mineiro, Leis Mineiras de 1875, Lei n 2181 de 25 de novembro de 1875.

26 O deputado Candido de Oliveira teve uma carreira política de destaque. Nascido em Ouro Preto em 1845, foi servidor público e magistrado. Foi promotor em Ouro Preto, procurador fiscal da tesouraria da fazenda, juiz municipal de Curvelo, ministro da Guerra, ministro da Justiça e ministro da Fazenda de forma interina. Foi vereador por um mandato, deputado provincial por 3 mandatos, deputado geral também por 3 mandatos e senador por um mandato entre os anos de 1887 e 1889. 
apresentadas no projeto. Seu discurso foi um depoimento sobre o tráfico de cativos na província, bem como sobre a situação da escravidão em Minas Gerais na década de 1870.

O deputado começou argumentando contrariamente à Lei do Ventre Livre de 1871, afirmando que foi ela que gerou a decadência da lavoura, dando origem à grande movimentação de escravos da província em direção à Zona da Mata. Para ele,

Quando a lei dita da emancipação foi imprudentemente imposta a este paiz [sic], que para ella [sic] não estava preparado, que já vai dolorosamente sentindo-lhe as funestissimas [sic] conseqüências [sic], porque a lavoura decahe [sic], esta quasi [sic] em liquidação, como bem disse meu ilustre amigo e collega [sic], no começo da execução da reforma de 1871, houve uma corrente, uma, por assim dizer, vertiginosa emigração do elemento servil. As zonas mais ricas, denominadas da matta [sic], depressa chamarão á si, pela exageração dos preços, os escravos do interior. Foi então que esse commercio [sic], inda ha pouco acanhado e limitadíssimo, tomou esse prodigioso incremento dos dias próximos. ${ }^{27}$

Argumentava o deputado que a Lei de 28 de setembro de 1871, iniciou, por parte dos cafeicultores, uma busca por escravos para suprir a falta de braços nas lavouras de café. Segundo o parlamentar, a alta nos preços fez com que os escravos fossem trazidos do interior de Minas, da Bahia, de Pernambuco e de outras províncias do norte em direção às zonas mais ricas.

V. Exc. Sr. Presidente, que, como eu fui, é habitante do sertão, lembra-se o como affluião [sic] para aquellas [sic] paragens bandos de negociantes, fazendo grandes levas de escravos que ião [sic] revender na matta [sic]. Foi esse o primeiro resultado da lei de 28 de Setembro. A avidez, com que os fazendeiros de café acolhião [sic] as compras e vendas de escravos, era o desesperado recurso da lavoura, que queria aproveitar os últimos braços, que, para supprir [sic] os vácuos que nas fileiras de seus instrumentos de trabalho operavão [sic] a morte e outras causas, proporcionavão-lhe [sic] esses agentes do deshumano commercio [sic].

D’hai [sic] essas numerosas transmissões de escravos, d'ahi [sic] essa elevação de preços, e a constante emigração de milhares d'elles [sic] do interior de Minas, dos sertões da Bahia, de Pernambuco e de outras províncias do norte. ${ }^{28}$

Após expor as razões da intensificação do tráfico de escravos na província, o deputado afirmou que o comércio de cativos, naquele momento, já não era mais o mesmo do período após 1871. Ele acreditava que já não havia mais braços disponíveis no interior da província, e que os que ainda restavam eram apenas os indispensáveis para a manutenção da vida local.

Mas, Sr. Presidente, eu quisera que a nobre comissão, com a experiência que lhe proporcionão [sic] os factos [sic], com sinceridade dissesse-nos

27 Arquivo Público Mineiro - Anais da Assembleia Legislativa Provincial de Minas Gerais de 1877, Seção de 28 de outubro de 1877.

28 Idem. 
se pensa que ainda concorrem as mesmas causas, todas as passageiras, para o desenvolvimento de semelhante commercio [sic]? O interior da província esta esgotado, não se pode tirar d'ahi [sic] mais braços escravos, porque os que existem são apenas os indispensáveis para a manutenção da vida local, da pequena lavoura interna. ${ }^{29}$

Dessa forma, o deputado questionava a estimativa feita para os impostos sobre compra, venda e transmissão de escravos, bem como para o imposto sobre o comércio de escravos. Para o deputado a receita proveniente destes impostos estava superestimada.

Já na sessão de 10 de dezembro de 1879, em que foi debatido o orçamento provincial, o deputado dr. Francisco Bernardino Rodrigues Silva, da região de Juiz de Fora, questionou a estimativa feita para a receita proveniente do imposto sobre a transferência e comércio de escravos. O deputado argumentava que tais tributos seguiam um padrão de arrecadação que dependia do comportamento das lavouras de café. Segundo ele, a colheita seguia um padrão oscilante, em um ano abundante, em outro, escassa. Comportamento este que também se observava na arrecadação do imposto da meia sisa e sobre o comércio de escravos. Observava o deputado "que no anno [sic] de producção [sic] abundante de café rende proporcionalmente menos o imposto de meia sisa e commercio [sic] de escravos"..$^{30}$

A explicação residia no fato de que, após uma colheita abundante, os cafeicultores buscavam melhorar as lavouras e aproveitavam os bons resultados das colheitas para adquirir mais escravos e disponibilizar mais braços para as plantações.

Naturalmente a explicação do facto [sic] é esta: os fazendeiros comprão [sic] o escravo justamente depois da colheita abundante, depois de realisal-a [sic], quando tem á sua disposição sommas [sic] avultadas. Cuidão [sic] então de melhorar suas lavouras, augmentando [sic] o numero de braços. Semelhantes compras se effectuão [sic], pois, no exercício subseqüente ao da boa colheita. ${ }^{31}$

O último imposto adotado em Minas Gerais e que incidia sobre a escravidão foi criado, em 1880, com o objetivo de acabar com a entrada de escravos de outras províncias.

É conhecido que o fim do tráfico internacional em 1850, com a Lei Eusébio de Queiroz, deu início a um intenso comércio interprovincial de escravos. A literatura acredita que esse comércio foi muito intenso durante as três décadas posteriores ao fim do comércio internacional, tendo acabado ou, pelo menos, diminuído substantivamente no início dos anos de 1880, com a promulgação de leis nas províncias de São Paulo, Rio de Janeiro e Minas Gerais, que tributavam, pesadamente, a entrada de escravos em seus territórios.

Há na historiografia um debate em torno dos interesses que levaram as províncias a obstaculizarem o comércio interprovincial de cativos. Para Warren Dean, ${ }^{32}$

29 Idem.

30 Arquivo Público Mineiro - Anais da Assembleia Legislativa Provincial de Minas Gerais de 1879, Sessão de 10 de dezembro de 1879 .

31 Idem.

32 DEAN, Warren. A Industrialização de São Paulo (1880-1945), São Paulo: DIFEL, sem data. 
as tentativas de frear o comércio interprovincial de escravos da província de São Paulo, no final da década de 1870, tinham o interesse de contribuir para o aceleramento da abolição, bem como estimular o fluxo de trabalhadores livres. Para o autor,

\begin{abstract}
os paulistas acabaram compreendendo que precisavam fomentar ativamente a conversão num sistema de trabalho livre se quisessem que a economia de exportação continuasse a crescer [...] Percebeuse, também a necessidade de abolir rapidamente a escravidão, a fim de estimular o fluxo de trabalhadores livres. EM 1878, a Assembleia procurou tributar o comercio interestadual de escravos, mas viu-se obstada pela corte por vários anos." ${ }_{33}$
\end{abstract}

A província do Rio de Janeiro foi a primeira a tributar a entrada de escravos em 1880, seguida por Minas Gerais, no mesmo ano, e por de São Paulo no ano de 1881. Para Paula Beiguelman, ${ }^{34}$ o interesse no fim do comércio interprovincial de escravos da província paulista estava no aumento da importância dos interesses imigrantistas.

Já Evaldo Cabral de Melo ${ }^{35}$ coloca o fato como o resultado do acirramento dos conflitos regionais provenientes da aprovação da Lei do Ventre Livre. Para o autor, o tráfico interprovincial, ao deslocar os escravos do Norte para as zonas cafeeiras, colocava os interesses regionais em lados opostos. O Norte apresentavase desinteressado pela escravidão, enquanto o Sul cafeeiro, dependente da mão de obra escrava. Para os interesses sulinos, o desinteresse pela escravidão do Norte, demonstrado principalmente na aprovação da Lei Rio Branco, e a maciça transferência de escravos das províncias nortistas para as regiões cafeeiras, ameaçavam o equilíbrio regional e poderiam criar dois brasis, um escravo e outro não. Sendo assim, o comércio interprovincial representava uma grande ameaça.

Na mesma linha vai Robert Conrad, ${ }^{36}$ que acredita que, para São Paulo a intenção de deter o tráfico provinha da necessidade de fortalecer o compromisso dos fazendeiros do Norte com a escravidão. O autor acredita, entretanto, que as tentativas das províncias paulista, mineira e carioca acabaram por fortalecer o abolicionismo no Norte, e não o contrário.

Fica clara, a partir da leitura da historiografia que procurou abordar o tema, uma forte tendência em privilegiar o caso paulista, e os motivos que levaram os cafeicultores paulistas a se interessarem pelo fim do comércio interprovincial de escravos. Tratado de forma ilustrativa, ou simplesmente como apêndice do caso paulista, o caso da província de Minas Gerais não tem tido análise mais aprofundada que busque apresentar os interesses da província sobre o fim de tal comércio.

Com a Lei $n^{\circ} 2716$ de 18 de dezembro de 1880 , que definia o orçamento provincial, foi criado o imposto de 2 contos de réis sobre cada escravo que viesse residir na província, em virtude de compra, troca, doação ou locação por mais de um ano.37

O exame dos debates parlamentares na Assembleia Provincial ilustra a questão e ajuda a entender o sentido da adoção do imposto. Em sessão de 7 de dezembro de 1880 , durante a discussão do projeto de lei do orçamento provincial,

33 Idem, p. 42.

34 BeiguelmAN, Paula. A Formação do Povo no Complexo Cafeeiro: aspectos políticos. São Paulo: Pioneira, 1978.

35 MELO, Evaldo Cabral de. O Norte agrário e o Império: 1871-1889. Rio de Janeiro: Nova Fronteira, 1984.

36 CONRAD, Robert. Os Últimos anos da escravatura no Brasil: 1850-1888. Rio de Janeiro: Civilização Brasileira, 1975.

37 Arquivo Público Mineiro, Leis Mineiras de 1880, Lei nº 2716 de 18 de dezembro de 1880. 
o deputado dr. Manoel Faustino Correa Brandão apresentou uma emenda que propunha um imposto de 500 réis sobre cada escravo que entrasse na província. O imposto foi aprovado, mas a emenda do deputado Faustino foi substituída, e o tributo estipulado em 2 contos de réis.

Ao justificar a adoção do imposto, o deputado manifestou preocupação com o crescimento do movimento abolicionista, que foi classificado por ele como perigoso para uma província onde a principal indústria era a agrícola. Dizia o deputado Manuel Faustino,

As ultimas noticias, chegadas da corte, não podem deixar de produzir grave impressão sobre nós, que somos representantes de uma província, cuja principal industria é a lavoura. Refiro-me à propaganda abolicionista, que vae [sic] se desenvolvendo na capital do império de um modo alias perigoso. ${ }^{38}$

Para ele, era preciso tomar providências sobre o que classificava como a "direção exagerada e inconveniente" que vinha tomando o movimento abolicionista naquele momento. Dessa forma, o deputado propunha o imposto com o objetivo de evitar, ou pelo menos diminuir, os prejuízos que o surto emancipacionista poderia causar.

Srs., essas ideas philantropicas [sic] encontrão guarida no coração de todos os mineiros; mas, tomando uma direção exagerada e inconveniente, como parece que vae [sic] tendo, pode acarretar e eu, entendendo que devemos evetal-os [sic], ou pelo menos minorar a sua extensão, tanto quanto caiba em nossas attribuições [sic], neste sentido formulei este additivo [sic]. ${ }^{39}$

Como podemos notar, os objetivos do deputado eram, principalmente, de prevenir distúrbios na província, bem como de defender o direito de propriedade, evitando a depreciação do cativo, mostrando preocupação com a substituição do trabalho escravo pelo trabalho livre. Além disso, dizia que sua emenda buscava contribuir para aumentar a arrecadação provincial.

Como vê a assemblea [sic], este additivo [sic] tem três bases: $1^{\text {a }}$ um principio social, que é evitar certos distúrbios e desordens, que se têm dado, cuja historia me absterei de desenvolver, porque a matéria é melindrosa; $2^{a}$, o direito de propriedade, por isso que adoptada [sic] esta medida, entendo que o elemento servil em nossa província não se depreciará, posto que nós devamos, o mais breve que for possível, tratar de substituir o trabalho escravo pelo trabalho livre. Este desideratum [sic], porem, é tão elevado quão difícil; desde que os altos poderes do Estado não têm podido resolver esta questão satisfactoriamente [sic], muito menos o poderei eu, simples pensador a este respeito; $3^{\text {a }}$ base da emenda é contribuir mais ou menos para o augmento [sic] das rendas da província. ${ }^{40}$

38 Arquivo Público Mineiro - Anais da Assembleia Legislativa Provincial de Minas Gerais de 1880, Sessão de 7 de dezembro de 1880 .

39 Idem.

40 Idem. 
O breve discurso do deputado Manoel Faustino sugeria que os interesses mineiros, ao adotarem tal imposto, pareciam diferir dos que motivaram São Paulo a seguir o mesmo caminho em 1881. O forte apego da província mineira à escravidão e as diferenças econômicas, que já na década de 1880 se mostravam significativas, sugerem preocupações e motivações distintas, mesmo que a preocupação maior com a preservação da instituição e um projeto de transição para o trabalho livre parecessem sempre ser um denominador comum dos interesses das duas províncias.

Já no ano de 1881, em sessão de 5 de outubro, que discutia o orçamento provincial, o deputado Manoel Faustino, opinando sobre a questão da colonização estrangeira na província, relembrou o seu projeto e afirmou ser seu dever cuidar para que fossem introduzidos braços em Minas que substituíssem os cativos.

\begin{abstract}
Entendo que a mim especialmente corre o dever de curar deste assumpto, pois que, não obstante ser o mais humilde membro desta casa (não apoiado), coube-me a honra de offerecer [sic] o anno [sic] passado uma medida prohibitiva [sic] da introducção [sic] de braços escravos na província.

Conhecendo o alcance dessa medida, que fechou as portas da província ao elemento servil, e tendo esta assemblea [sic] constantemente procurado facilitar o transporte de productos [sic] da lavoura, já por meio de vias férreas, já por meio de estradas de outra ordem; é meu rigoroso dever concorrer com o meu fraco contingente para prover a lavoura de elementos indispensáveis para desenvolver a sua producção [sic] e dest'arte [sic] poder manter essas vias de comunicação. É uma conseqüência necessária das premissas estabelecidas por esta assemblea [sic].

[...] Justamente; porque, desde que fechamos as portas ao elemento servil, desde que facilitamos os meios de transporte, dando a província estradas de ferro e outras vias de communicação [sic], a conseqüência [sic] necessária é termos o que transportar, e pra que tenhamos o que transportar, precisamos ter braços, que produzão [sic]: é o raciocínio que não podemos fugir ${ }^{41}$
\end{abstract}

O deputado acreditava que só substituindo o trabalhador escravo pelo livre é que se poderia obter um processo de emancipação servil favorável e oportuno aos agricultores. Assim, acreditava que medidas nesse sentido eram necessárias para dotar a província de mão de obra capaz de trabalhar na lavoura, tornando menor a necessidade do trabalho escravo. Para o deputado Faustino, o caminho a seguir era o da imigração. Usando o exemplo dos Estados Unidos, ele via a imigração estrangeira como indispensável para o desenvolvimento do país e da província. Citando um pensamento de um presidente americano, ele disse:

A emigração é um elemento de prosperidade nacional, cuja importância é difícil exagerar. O estrangeiro moralisado [sic], trabalhador traz nos aquillo [sic] de que mais precisamos - a habilidade e os braços.

É, Sr., agrupando-nos em torno desta idea [sic], que conseguiremos a resolução pratica do problema da emancipação servil. É promovendo sua substituição, é collocando [sic] o braço livre no espaço até

41 Arquivo Público Mineiro - Anais da Assembleia Legislativa Provincial de Minas Gerais de 1881, Seção de 5 de outubro de 1881. 
agora occupado [sic] pelo braço escravo, que faremos desaparecer a necessidade deste. Assim todas as medidas, que forem tomadas no sentido de fazer diminuir, ou melhor, acabar a grande força da necessidade, que temos, de braços, contribuirão efficazmente [sic] para a emancipação, sendo estes os verdadeiros meios de evitarmos os perigos, os factos [sic] criminosos, os assassinatos, que todos os dias lemos nos jornaes [sic] e de que são victimas [sic] os nossos fazendeiros. Faço justiça a todos os brasileiros, todos os mineiros, porque todos pensão da mesma forma (...) mas nas condições, em que nos achamos todas as providencias tomadas no sentido que acabo de expor, isto é, no de substituição do elemento servil, são as que me parecem mais convenientes para conseguir-se a emancipação opportunamente [sic] e para a segurança da vida dos que se dedicão [sic] à agricultura, cujos producto [sic] constituem a principal fonte de nossa riqueza publica, repito, estando nella [sic] baseada a prosperidade do paiz [sic] e especialmente a da nossa província. ${ }^{42}$

O discurso do deputado, entretanto, pode confundir. Apesar de manifestarse claramente favorável à imigração e à colonização estrangeira, como forma de substituir o trabalho escravo, fica claro que a intenção dele, quando propôs a medida que fechou as portas da província à chegada de escravos, era mais especificamente substituir o trabalho escravo pelo livre como forma de proteger a agricultura e os agricultores mineiros de um colapso. A partir daí, afirmar que, assim como argumentam Dean e Beiguelman para São Paulo, o fim do comércio interprovincial de escravos foi uma medida para atender os interesses imigrantistas, talvez seja um exagero. Isso por razões até certo ponto claras: primeiramente porque, diferentemente da província paulista, Minas não estava atraindo imigrantes naquele momento, nem ao menos tinha leis muito claras nesse sentido. Além disso, não podemos afirmar que a imigração fosse um projeto claro e definido das elites e autoridades mineiras. Muitas vezes, os debates parlamentares mostravam que parte das autoridades acreditava que Minas atraía poucos imigrantes, por suas condições econômicas, e que, por isso, se devia tentar submeter ao trabalho o grande contingente de nacionais livres residentes no território mineiro.

A partir das leis orçamentárias e das estimativas feitas para a receita com os tributos provinciais, podemos traçar um perfil não só da escravidão, bem como do comércio de escravos na província, a partir da década de 1870.

A Tabela 1, na próxima página, mostra as estimativas de arrecadação com os impostos que incidiam sobre a escravidão a partir de 1874. Nesta Tabela faltam os dados para o ano de 1885, sendo importante notar que nos anos de 1874 e 1875 a rubrica "Transferência e registro de escravos" correspondia somente à arrecadação do imposto da meia sisa (sobre transferência de escravos), uma vez que o registro de escravos só passou a ser adotado a partir de 1876. 
Tabela 1 - Orçamento Provincial - previsão de receita com impostos que
incidiam sobre a escravidão 1874-1887

\begin{tabular}{cc|c|c}
$\begin{array}{c}\text { RUBRICA NO } \\
\text { ORÇAMENTO* }\end{array}$ & $\begin{array}{c}\text { TRANSFERENCIA E } \\
\text { REGISTRO }\end{array}$ & $\begin{array}{c}\text { ESCRAVOS EM } \\
\text { SERVIÇO DE } \\
\text { DE ESCRAVOS** }\end{array}$ & $\begin{array}{c}\text { MINERAÇÃO } \\
\text { ESCRAVOS }\end{array}$ \\
\hline 1874 & $182: 000 \$ 000$ & $2: 000 \$ 000$ & $6: 000 \$ 000$ \\
\hline 1875 & $340: 000 \$ 000$ & $1: 940 \$ 000$ & $12: 000 \$ 000$ \\
\hline 1876 & $390: 000 \$ 000$ & $1: 800 \$ 000$ & $50: 000 \$ 000$ \\
\hline 1877 & $390: 000 \$ 000$ & $1: 300 \$ 000$ & $50: 000 \$ 000$ \\
\hline 1878 & $330: 000 \$ 000$ & $1: 500 \$ 000$ & $50: 000 \$ 000$ \\
\hline 1879 & $300: 000 \$ 000$ & $1: 700 \$ 000$ & $35: 000 \$ 000$ \\
\hline 1880 & $340: 000 \$ 000$ & $1: 6000 \$ 000$ & $35: 000 \$ 000$ \\
\hline 1881 & $205: 000 \$ 000$ & $1: 6000 \$ 000$ & $20: 000 \$ 000$ \\
\hline 1882 & $220: 000 \$ 000$ & $1: 500 \$ 000$ & $15: 000 \$ 000$ \\
\hline 1883 & $220: 000 \$ 000$ & $1: 500 \$ 000$ & $5: 000 \$ 000$ \\
\hline 1884 & $130: 000 \$ 000$ & $1: 000 \$ 000$ & $1: 000 \$ 000$ \\
\hline 1886 & $80: 000 \$ 000$ & $1: 000 \$ 000$ & $1: 000 \$ 000$ \\
\hline 1887 & $80: 000 \$ 000$ & $1: 000 \$ 000$ & $2: 000 \$ 000$ \\
\hline
\end{tabular}

*Faltam os valores para o ano de 1885 .

** As estimativas para o anos de 1874 e 1875 correspondem somente ao imposto sobre a transferência de escravos.

Fonte: Arquivo Público Mineiro - Leis Mineiras dos anos de 1874 a 1887.

Devemos ressaltar que a Tabela corresponde aos dados existentes nas leis orçamentárias da província e, portanto, não correspondem aos valores efetivamente arrecadados a cada ano. Dessa forma, devemos levar em conta tanto certas superestimações como subestimações dos valores. Entretanto, tais estimativas oferecem um perfil do que, naquele momento, esperavam os deputados arrecadar com os impostos, e o estado em que acreditavam encontrarem-se tanto o regime escravista, quanto o comércio de escravos em Minas Gerais.

Podemos notar que até 1880 as estimativas tanto da receita proveniente das transferências e registros de escravos, como da receita com o comércio de escravos não apresentam variações tão significativas, o que sugere que somente após a adoção do imposto que visava acabar com a entrada de escravos na província esse tipo de comércio sofreu esfriamento. Portanto, é de se supor que, durante toda a década de 1870, o tráfico manteve-se e tinha importância e significado.

Outra questão interessante é que, mesmo com fim do tráfico interprovincial, o comércio de escravos dentro da província manteve certa importância nos anos de 1882 e 1883 , caindo um pouco em 1884 e definhando de vez a partir de 1886. Isso nos leva a supor que somente após a promulgação da Lei dos Sexagenários, em 1885, e a certeza da aproximação da abolição, o comércio de escravos perdeu definitivamente a sua importância.

O discurso do deputado Paixão ${ }^{43}$ em sessão de 20 de setembro de 1883,

43 O dr. Antonio Jacob da Paixão era político e advogado. Nasceu em Senhor do Bom Jesus do Rio Pardo, distrito de Pomba, em 1842. Estudou Humanidades, tendo concluído o curso de Filosofia. Especializado em Aritmética, Álgebra e Geometria habilitou-se para o magistério. Em 1875 bacharelou-se em Ciências Jurídicas e Sociais pela FDSP. Depois de formado, fixou residência em Rio Novo, onde iniciou a carreira política. Foi deputado provincial entre 1880-1885, tendo sido líder do Partido Liberal na Assembleia. Republicano confesso, foi vereador em Rio Novo. Foi deputado federal constitucional e na $1^{\text {a }}$ legislatura entre $1891-1893$ e na $3^{\text {a }}$ legislatura entre 1897-1890. Foi diretor do Banco Regional de Minas Gerais no Rio de Janeiro. No período imperial, era membro do Partido Liberal, já na República era membro do Partido 
que tratava do orçamento provincial, reforçava a ideia de que ainda, após o estabelecimento do imposto que dificultava o comércio interprovincial de escravos, o comércio de cativos no interior da província era forte. Dizia o deputado,

Consequentemente, se as medidas restrictivas [sic] d'este commercio [sic], isto é, aquellas [sic] que teem [sic] limitado ou impossibilitado o commercio inter-provincial [sic], procedem para a extincção [sic] completa do commercio [sic] de escravos na província do Rio de Janeiro, não procedem para a província de Minas, porque aqui, alem do commercio inter-provincial [sic], temos um commercio [sic] propriamente provincial e a respeito d'este não temos medida alguma restrictiva [sic], por quanto sabemos que a de que se trata não é nova e não produzirá effeito [sic] nenhum; continuarão os negociantes de escravos a sua profissão, como dantes, sem se receitarem d'esse imposto. ${ }^{44}$

A partir da história da tributação sobre a escravidão, pode-se traçar um perfil do regime escravista na província; buscar elementos para entender melhor o tráfico de escravos interprovincial e intraprovincial em Minas Gerais; além de compreender melhor a crise da escravidão, que marcaria toda a segunda metade do século XIX no Brasil.

O estudo dos tributos que incidiam sobre a escravidão no período provincial em Minas Gerais parece confirmar questões clássicas da historiografia em relação à diversidade regional mineira. Da mesma forma, parece apontar para o apego de algumas regiões mineiras ao sistema escravista, até o seu fim, assim como mostrar a importância do comércio de escravos na província até os últimos momentos do regime escravista no Brasil. ${ }^{45}$ Estamos certos de que os estudos da história tributária podem contribuir tanto para compreender não só a realidade econômica, mas também a realidade social e da crise da escravidão, assim como contribuir para uma melhor compreensão da transição do trabalho escravo para o trabalho livre no país.

A historiografia econômica sobre a transição do trabalho escravo para o trabalho livre no Brasil sempre, ou na maioria dos estudos, abordou questões referentes às regiões cafeeiras, onde a modernização capitalista ocorreu de forma mais clara e completa. Contudo, formação capitalista brasileira apresenta diferenças regionais importantes. O caso de Minas Gerais é emblemático, uma região em que uma das especificidades é justamente a diversidade econômica regional de seu território no século XIX. Tal constatação, presente nos trabalhos contemporâneos sobre a Minas oitocentista, aponta para o seu grande dinamismo econômico. ${ }^{46}$

Contudo, apesar disso, notamos que, no final do século XIX, esse dinamismo não se refletiu na modernização da economia rumo ao desenvolvimento capitalista. Assim sendo, Minas Gerais, que até a década de 1870 tinha um nível de

Republicano Mineiro. MONTEIRO, Norma de Góes (org.), Dicionário Biográfico de Minas Gerais - Período Republicano 1889/1991, Belo Horizonte: UFMG/Assembleia Legislativa do Estado de Minas Gerais, 1994.

44 Arquivo Público Mineiro - Anais da Assembleia Legislativa Provincial de Minas Gerais de 1883, Sessão de 20 de setembro de 1883.

45 COSENTINO. Um múltiplo de transições, 2006.

46 Sobre esta questão ver MARTINS. A economia escravista de Minas Gerais no século XIX; PAIVA, Clotilde Andrade. População e economia nas Minas Gerais do século XIX. Tese (Doutorado), USP/Faculdade de Filosofia, Letras e Ciências Humanas, 1996; PAIVA \& GODOY. Território de contrastes. 
desenvolvimento semelhante ao de São Paulo, ficou para trás do território paulista, não conseguindo dar o salto modernizante que em São Paulo foi impulsionado pelo desenvolvimento do café do oeste, com sua crescente produção ampliando terras e trabalho através da imigração.

Minas Gerais tinha uma economia dinâmica, porém apoiada na produção de gêneros de abastecimento interno e em uma reprodução que reforçava laços de dependência entre senhores e agregados, uma vez que as terras produtivas estavam em sua grande maioria apropriadas pelos senhores. Uma economia que não possibilitava uma acumulação capitalista, que tinha dificuldade de gerar um processo de proletarização, de submeter o homem livre ao trabalho e gerar uma oferta regular e disciplinada de força de trabalho, que tinha dificuldade e ausência de uma boa estrutura de transportes e, ainda, convivia com a ausência de um mercado capitalista. No essencial, a economia mineira era estruturada sobre uma economia de projeto não capitalista, apoiada sobre uma sociedade arcaica e patriarcal. ${ }^{47}$

Tudo isso iria se refletir no processo de transição do trabalho escravo para o livre, que se daria condicionada pela realidade da economia mineira no século XIX. Dessa forma, o processo em Minas Gerais não contou com a imigração, como na região cafeicultora de São Paulo, uma vez que atraía muito pouco os imigrantes, pela sua dinâmica produtiva e pelo seu apego ao regime escravista. Assim, o processo em Minas Gerais foi realizado a partir da mão de obra local e ex-escrava. Além disso, essa transição em Minas teve aspectos regionais importantes, dada a grande diversidade regional do território mineiro. ${ }^{48}$

O processo de crise da escravidão em Minas Gerais desencadeia uma série de tentativas e ideias para solucionar o problema da mão de obra. Tais projetos se refletem no debate na Assembleia Provincial, bem como nos tributos que incidiam sob a escravidão na província mineira. Percebemos, a partir do estudo de tais tributos, um grande apego de Minas à escravidão até o seu final. Além disso, foi possível reafirmar a sua diversidade regional e constatar a importância do comércio de escravos na província até os últimos momentos da escravidão no Brasil.

Ademais, a própria história da tributação sobre a escravidão reflete a dificuldade na condução do processo de transição do trabalho escravo para o livre, bem como do processo de modernização econômica de Minas Gerais.

Recebido em: 08/04/2013

Aprovado em: 05/06/2013

47 COSENTINO. Um múltiplo de transições.

48 Idem. 